\title{
PEMANFAATAN LIMBAH AMPAS TAHU DALAM UPAYA DIVERSIFIKASI PANGAN
}

\author{
Masyhura MD, Khairunnisa Rangkuti, Misril Fuadi \\ Fakultas Pertanian Universitas Muhammadiyah Sumatera Utara \\ Jalan Kapten Muktar Basri No. 3 Medan Indonesia \\ Masyhura@umsu.ac.id
}

\begin{abstract}
Tofu pulp is a by-product of tofu processing which still contains high enough protein because in the process of knowing not all proteins can be extracted. The focus of the problem on the local community starts from observations in the field where some people have a home industry that knows its pulp not yet maximally utilized only limited to animal feed additives. Based on this problem it is necessary to empower rural communities, especially household mother by providing counseling and training on the use of vilages such as tofu industry waste to be processed into useful products with high economic value.Tofu dregs become crackers and abon in addition to nutritious family food (food diversification) as well as additional household income.

Keywords: abon, tofu dregs, waste and crackers.
\end{abstract}

\section{A. PENDAHULUAN}

Tahu merupakan makanan kaya protein yang sudah menjadi bagian dari kehidupan masyarakat.Walaupun protein tahu tidak sebaik protein hewani, namun memiliki peranan yang sangat berarti dalam memperbaiki nilai gizi keluarga.

Pada proses pengolahan tahu akan dihasilkan limbah berupa ampas tahu yang apabila tidak segera ditangani, dapat menimbulkan bau tidak sedap. Limbah ampas tahu masih mengandung zat gizi yang tinggi yaitu protein (26.6\%), lemak (18.3\%), karbohidrat (41.3\%), fosfor $(0.29 \%)$, kalsium $(0.19 \%)$, besi $(0.04 \%)$ dan air (0.09\%). Oleh karena itu masih memungkinkan untuk dimanfaatkan sebagai bahan dasar atau campuran pada proses pengolahan pada poduk tertentu (Sulistiani, 2004).

Desa Purwodadi merupakan salah satu desa di Kecamatan Pagar Merbau Kabupaten Deli Serdang Propinsi Sumatera Utara, dengan jarak dari kota Medan lebih kurang 39 kilometer. Luas
Desa Purwodadi lebih kurang 82 ha dengan jumlah penduduk 2831 jiwa dengan mata pencarian yang beragam diantaranya adalah home industri pengolahan tahu.

Lokasi mitra mempunyai pabrik pengolahan tahu yang selama ini limbahnya belum dimanfaatkan secara maksimal hanya sebatas untuk makanan ternak dengan nilai jual yang rendah. Limbah ampas tahu mempunyai nilai protein yang masih cukup tinggi sehingga baik untuk diolah menjadi produk makanan dalam upaya diversifikasi pangan.

Masyarakat terutama ibu-ibu di lokasi mitra ratarata pekerjaannya sebagai ibu rumah tangga yang masih banyak waktu luang dan pengetahuan tentang gizi yang minim . Dengan diberi penyuluhan gizi dan bagaimana mengolah ampas tahu dalam upaya diversifikasi pangan yang akan menambah pengetahuan dan meningkatkan pendapatan dengan menjual produk olahan yang mereka hasilkan

Untuk mengatasi permasalahan yang ada pada kedua mitra maka tim pengabdian masyarakat 
Masyhura, et all . / Agrintech | Jurnal Teknologi Pangan dan Hasil Pertanian 2 (2) 2019, 52-54

Fakultas Pertanian UMSU akan melakukan penyuluhan tentang gizi dan pelatihan bagaimana cara pengolahan ampas tahu menjadi produk olahan dalam upaya diversifikasi pangan dalam hal ini pembuatan abon dan pembuatan kerupuk dari ampas tahu.

Adapun bahan baku yang digunakan berasal dari limbah pabrik pengolahan tahu yang ada di desa tersebut, Limbah yang dihasilkan berupa ampas tahu yang selama ini hanya digunakan sebagai makanan ternak yang dijual dengan harga yang relatif rendah, dengan diolahnya ampas tahu menjadi produk olahan pangan yang bergizi tinggi dalam pemenuhan kebutuhan pangan keluarga juga akan meningkatkan nilai jual produk olahan menjadi lebih baik sehingga menambah pendapatan ibu-ibu yang ada di desa tersebut.

\section{B. METODE PELAKSANAN}

Metode pelaksanaan pada program ini adalah dengan melakukan penyuluhan atau sosialisasi kepada mitra mengenai program yang akan dilaksanakan :

1. Penyuluhan ini diberikan materi tentang gizi bagaimana meningkatkan gizi keluarga yang sehat.

2. Melakukan pelatihan pembuatan abon dan kerupuk dari ampas tahu.

\section{HASIL DAN PEMBAHASAN}

\section{Melakukan Penyuluhan Tentang Kandungan} Gizi dari Ampas Tahu

Sebelum penyuluhan tentang gizi dilakukan, terlebih dahulu kedua mitra yang terdiri dari kelompok Dasa wisma Dahlia dan kelompok Dasa Wisma Cendana dikumpulkan di rumah Ibu
Kepala Desa ( Ayu Selly ) yang merupakan Ketua tim Penggerak PKK Desa.

Penyuluhan tentang gizi disampaikan bahwa kandungan gizi dari ampas tahu masih banyak. Ampas tahu masih mengandung zat gizi yang tinggi yaitu protein (26.6\%), lemak (18.3\%), karbohidrat (41.3\%), fosfor (0.29\%), kalsium $(0.19 \%)$, besi $(0.04 \%)$ dan air $(0.09 \%)$. Oleh karena itu masih memungkinkan untuk dimanfaatkan sebagai bahan dasar atau campuran pada proses pengolahan pada poduk tertentu ( Sulistiani, 2004). Dan bagaimana memotivasi mitra agar mandiri secara ekonomi dengan memanfaatkan potensi sumber daya yang ada didesa yaitu Pemanfaatan Ampas Tahu Dalam Upaya Diversifikasi Pangan yang bernilai gizi tinggi dan bernilai ekonomis.

\section{Mendemonstrasikan Pembuatan Abon dan Kerupuk Ampas Tahu}

Mitra diajarkan bagaimana membuat Abon dan Kerupuk Ampas Tahu dan juga melibatkan peserta/mitra untuk langsung ikut dalam proses pengolahan tersebut. Disamping itu peserta juga diajarkan membuat variasi olahan Abon dan Kerupuk Ampas Tahu dengan menambah berbagai bumbu ataupun essense yang berbeda sehingga dihasilkan Abon dan Kerupuk Ampas Tahu yang variatif. 

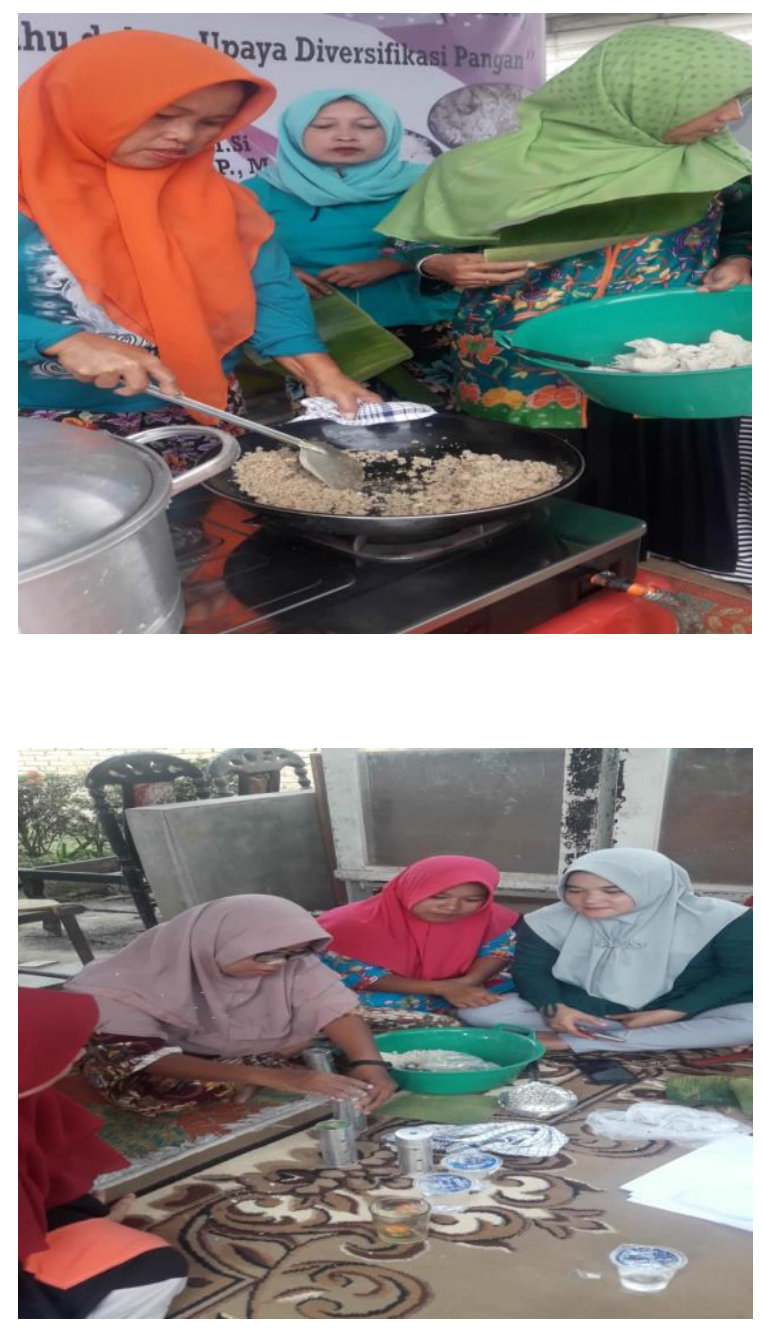

\section{KESIMPULAN}

Dengan diberikan penyuluhan tentang kandungan gizi dari ampas tahu dan pelatihan pengolahan ampas tahu menjadi kerupuk dan abon diharapkan ibu- ibu PKK Desa Purwodadi kecamatan Pagar Merbau Kabupaten Deli Serdang mengerti dan mampu mengolahannya sehingga dapat dikembangkan di masyarakat dalam meningkatkan gizi dan pendapatan keluarga.

\section{UCAPAN TERIMAKASIH}

Penulis mengucapkan terimakasih kepada Lembaga Penelitian dan Pengabdian Masyarakat Universitas Muhammadiyah Sumatera Utara yang telah mendanai Program Kemitraan Masyarakat dengan judul "Pemanfaatan Limbah Ampas Tahu Dalam Upaya Diversifikasi Pangan" dan tak lupa penulis mengucapkan terima kasih kepada ibu PKK Desa Purwodadi Kecamatan Pagar Merbau Kabupaten Deli Serdang yang telah berperan aktif pada Program Kemitraan Masyarakat (PKM) ini.

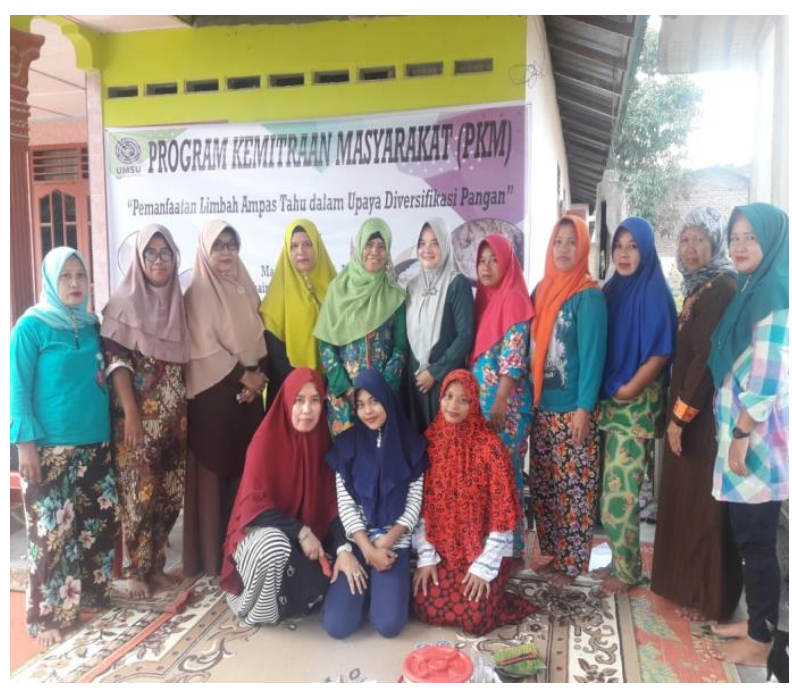

\section{DAFTAR PUSTAKA}

Sulistiani, 2004. Pemanfaatan Ampas Tahu Sebagai Bahan Alternatif Bahan Baku Pangan Fungsional. IPB. Bogor. 